\title{
ANALISIS KEJADIAN COVID-19 PADA REMAJA PENYINTAS BERDASARKAN IDENTITAS DIRI DAN DUKUNGAN SOSIAL DI RUMAH SAKIT SILOAM SEMANGGI JAKARTA
}

\author{
Naziyah $^{1^{*}}$, Andi Julia Rifiana ${ }^{2}$, Hilda Mariyana ${ }^{3}$ \\ ${ }^{1-3}$ Universitas Nasional Jakarta \\ Email Korespondensi: naziyah@civitas.unas.ac.id
}

Disubmit: 22 Januari 2022 Diterima: 23 Januari 2022 Diterbitkan: 01 Februari 2022

DOI: https://doi.org/10.33024/mnj.v5i2.5890

\section{ABSTRACT: ANALYSIS OF THE EVENT OF COVID-19 IN ADOLESCENT SURVIVAL IN SILOAM SEMANGGI HOSPITAL JAKARTA}

Background: The World Health Organization (WHO) announced a case of pneumonia that occurred in Wuhan China in December 2019. Pneumonia cases occurred caused by the latest corona virus named COVID-19 which means coronavirus disease 2019. Corona virus is a pandemic disease which means that this deadly virus is spreading beyond prevention efforts in most countries in the world. By studying Health data from more than 230,000 patients who recovered from COVID-19, researchers found $34 \%$ of survivors were diagnosed with neurological or mental problems within 6 months. Within 3 months of testing positive for COVID-19, one in five people who have recovered will be diagnosed with anxiety, depression and insomnia. Moreover, there is a negative stigma and lack of social support that causes low self-esteem and loss of self-identity. And our findings show that possibility for adolescents.

Purpose: This study aims to determine the relationship between Self-Identity in Adolescent Survivors and Social Support in Adolescent Survivors .

Method: This study uses a descriptive correlation design with approach cross sectional. The time of the study was carried out on 25 November - 13 Desember 2021. Sampling technique using themethod purposive sampling technique.Data were collected by distributing questionnaires Marcia-Erickson Self-Identity and Sarason's Social Support questionnaires to 92 respondents. The statistical test uses thetest Chi-square.

Results: The results of this study found that the adolescent survivors who had a good self identity 88 respondents by percentage $(80,9 \%)$. Obtained with $p$ value $(0.000)(p, 0,05)$.

Conclusions : There is relationship between self identity in adolescent survivors and social support in adolescent survivors.

Keywords: Covid-19, Self Identity,Social Support 


\section{INTISARI: ANALISIS KEJADIAN COVID-19 PADA REMAJA PENYINTAS BERDASARKAN IDENTITAS DIRI DAN DUKUNGAN SOSIAL DI RS SILOAM SEMANGGI JAKARTA}

Latar Belakang: World Health Organization (WHO) mengumumkan kasus Pneumonia yang terjadi di Wuhan Tiongkok pada Desember 2019. Kasus pneumonia terjadi disebabkan oleh virus corona terbaru yang bernama COVID-19 berarti coronavirus disease 2019. Virus Corona sebagai penyakit pandemi yang berarti virus yang mematikan ini menyebar di luar upaya pencegahan di sebagian besar negara di dunia. Dengan mempelajari data Kesehatan dari lebih 230 ribu pasien yang sembuh dari covid19, para peneliti menemukan $34 \%$ dari para penyintas didiagnosa mengalami masalah neurologis atau mental dalam tempo 6 bulan. Dalam 3 bulan setelah dites positif Covid19, satu dari lima orang yang dinyatakan sembuh didiagnosa mengalami kecemasan,depresi dan insomnia. Terlebih alih-alih terdapat stigma negative dan kurangnya dukungan social yang menyebabkan rendah diri dan kehilangan identitas diri. Dan temuan kami menunjukkan kemungkinan itu terhadap Remaja.

Tujuan: Penelitian ini bertujuan untuk mengetahui hubungan Identitas Diri pada Remaja Penyintas dan Dukungan Sosial pada Remaja Penyintas.

Metode Penelitian: Penelitian ini menggunakan desain deskriptif korelasi dengan pendekatan cross sectional. Waktu penelitian dilaksanakan 25 November - 13 Desember 2021.Teknik Sampling dengan menggunakan metode purposive sampling.Data yang dikumpulkan dengan cara menyebarkan kuesioner Identitas Diri Marcia (Erickson) dan kuisioner Dukungan Sosial Sarasons kepada responden yang berjumlah 92 responden. Uji statistik menggunakan uji Chi-square.

Hasil: Hasil penelitian ini didapatkan bahwa ada hubungan signifikan antara variable identitas diri dan dukungan sosial yaitu penyintas covid-19 remaja mempunyai identitas diri baik sebanyak 88 responden dengan persentase $(80,9 \%)$. Diperoleh dengan hasil $p$-value $(0,000)(p, 0,05)$.

Kesimpulan: Terdapat hubungan anatara identitas diri dan dukungan sosial remaja penyintas Covid-19.

Kata kunci: Covid-19, Identitas Diri, Dukungan Sosial.

\section{PENDAHULUAN}

World Health Organization

(WHO) mengumumkan kasus

Pneumonia yang terjadi di Wuhan

Tiongkok pada tanggal 31 Desember 2019. Kasus pneumonia terjadi disebabkan oleh virus corona terbaru yang bernama COVID-19 berarti coronavirus disease 2019 (Hartati \& Susanto, 2020). Pada bulan Maret 2020, WHO tersebut menyebut Virus Corona sebagai penyakit pandemi yang berarti virus yang mematikan ini menyebar di luar upaya pencegahan di sebagian besar negara di dunia. Dalam Kamus Besar Bahasa Indonesia, pandemi adalah sebuah epidemi yang telah menyebar ke beberapa negara atau bahkan benua, dan umumnya menjangkit banyak orang. Dalam kasus saat ini, covid-19 menjadi pandemi pertama yang disebabkan oleh virus corona. (Hartati \& Susanto, 2020)

Virus Corona mempengaruhi kehidupan sosial individu karena banyak sekolah, perguruan tinggi, universitas, pub, restoran, kafe, dll. telah ditutup. Banyak festival, upacara keagamaan dan sosial tibatiba dibatalkan atau ditunda. Bahkan konferensi tentang Virus Corona sendiri telah dihapus. UNESCO 
(2020) dalam resent mereka laporan mengungkapkan "Pemerintah di 61 negara telah mengumumkan atau menerapkan penutupan lembaga pendidikan dalam upaya untuk memperlambat penyebaran penyakit". Lalu, lebih dari 39 negara telah menutup sekolah, dan perguruan tinggi, yang telah berdampak pada lebih dari 420 juta anak dan remaja. (Singh, 2020).

Jumlah kasus yang semakin hari semakin naik turun dan beragam masalah dan kebijakan yang silih berganti di Indonesia. Tidak jarang kita temui kasus di tatanan pekerjaan, masyarakat dan keluarga. Maka, Mahasiswa Keperawatan harus mampu mengenal tanda dan gejala sedini mungkin dan ketika menemukan kasus tersebut mahasiswa mampu memberikan pertolongan pertama pada klien. Dan sebagai pemberi asuhan keperawatan mempunyai peran penting dalam membantu meningkatkan konsep diri yaitu identitas diri penyintas Covid19. Terlebih dari itu baik penyandang Covid 19 dan penyintas Covid 19 adalah sama mempunyai pandangan,keadaan dan konsep diri yaitu identitas diri yang bisa saja merosot atau berubah menjadi lebih baik. Terlebih di tatanan usia remaja. Sarwono (2015) menjelaskan, pada masa remaja awal, individu akan mengalami fase peralihan dan masih mengalami kebingungan pada perubahanperubahan secara fisik yang terjadi pada tubuhnya sendiri, belum mampu mengontrol emosinya sendiri, tidak stabil, tidak puas, rendah diri, dan cepat merasa kecewa. Menurut Jahja (2015), pada masa ini peningkatan emosional terjadi sangat cepat, sehingga masa remaja awal dikenal sebagai masa penuh badai dan tekanan. Disamping itu, remaja pada fase ini banyak terjadi tuntutan dan tekanan yang ditunjukkan pada remaja, misalnya mereka diharapkan untuk tidak lagi bertingkah seperti anak-anak, lebih mandiri dan bertanggung jawab. Pada masa remaja madya, akan muncul kemantapan yang menjawab keragu-raguan pada masa remaja awal, dan mulai dapat memunculkan rasa percaya diri serta individu sudah mampu menemukan diri sendiri atau jati dirinya. Sedangkan pada fase remaja akhir, individu sudah mengenal dirinya, mulai memahami arah hidupnya dan menyadari tujuan hidupnya. Erikson (dalam Gross, 2016). Berarti masa dimana mereka sedang berpikir lebih banyak,mencari tahu lebih banyak,memilih sesuai persepsi dan pandangannya bisa beralasan atau hanya ikut-ikutan. Menurut WHO, yang disebut remaja adalah mereka yang berada pada tahap transisi antara masa kanak-kanak dan dewasa. Batasan usia remaja menurut WHO adalah 12 sampai 24 tahun. (WH0,2020)

Tentang penyintas Covid19 sendiri, penelitian yang diterbitkan di jurnal Lancet Psychiatry, Rabu (7/4), membuktikan bahwa pasien covid-19 lebih mungkin mengalami masalah pada otak ketimbang mereka yang mengalami infeksi saluran pernafasan lainnya. Dengan mempelajari data kesehatan dari lebih dari 230 ribu pasien yang sembuh dari covid-19, para peneliti menemukan 34\% dari para penyin tas didiagnosa mengalami masalah neurologis atau mental dalam tempo enam bulan. Gangguan neurologis yang paling banyak dialami penyintas covid-19 adalah rasa cemas (17\% pasien) atau gangguan mood $(14 \%)$. Bagi $13 \%$ penyintas covid-19, gangguan neurologis itu merupakan kali pertama mereka didiagnosa dengan gangguan kesehatan itu. Para peneliti juga mempelajari data dari lebih dari 100 ribu pasien influenza dan data dari 
lebih dari 236 ribu pasien infeksi saluran pernafasan. Hasilnya, penyintas covid-19 memiliki risiko mengalami gangguan neurologis atau mental 44\% lebih tinggi ketimbang penyintas fly dan $16 \%$ lebih tinggi dari penderita infeksi saluran pernafasan. (AFP/OL-1-Lanset

Psychiatry-2020)

Riset lainnya juga mengungkap bahwa masalah gangguan mental yang paling umum dialami pasien Covid-19 yang sembuh adalah kecemasan, depresi, dan insomnia. "Orang-orang khawatir bahwa mereka yang sembuh dari Covid-19 berisiko lebih besar mengalami masalah kesehatan mental. Terlebih alih-alih terdapat stigma negative dan kurangnya dukungan social yang menyebabkan rendah diri dan kehilangan identitas diri. Dan temuan kami menunjukkan kemungkinan itu," kata Paul Harrison, seorang profesor psikiatri di Universitas Oxford Inggris yang terlibat dalam studi. Menurut Harrison (2020) juga mengatakan dokter dan ilmuwan di seluruh dunia harus segera menyelidiki penyebabnya dan mengidentifikasi perawatan baru untuk masalah mental,konsep diri bahkan dukungan social yang harusnya menjadi termotivasi usai terinfeksi Covid-19. "Pelayanan kesehatan harus siap memberikan perawatan," tambahnya. Peneliti riset yang berasal dari Universitas Oxford Inggris juga menemukan adanya risiko demensia, kondisi gangguan otak, yang jauh lebih tinggi pada penyintas Covid-19. (Harrison,2020)

\section{METODE PENELITIAN}

Desain penelitian ini adalah investigasi kuantitatif dengan menggunakan desain deskriptif korelasi dengan pendekatan cross sectional. Populasi dalam penelitian ini adalah seluruh remaja penyintas Covid-19 di Siloam Hospitals Semanggi sebanyak 120 orang. Sample dalam penelitian ini adalah remaja penyintas Covid-19 yaitu responden yang terdiri dari 52 remaja perempuan dan 40 remaja laki-laki. dengan menggunakan purposive sampling. Variabel bebas dalam penelitian ini adalah identitas diri dan dukungan sosial dimana variabel tersebut merupakan faktor yang berhubungan dengan kejadian Covid-19 pada remaja penyintas yang dalam penelitian ini merupakan variabel terikat.

Penelitian ini dilaksanakan pada tanggal 25 November - 13 Desember 22021 di Siloam Hospitals Semanggi. Jenis instrumen alat yang digunakan adalah kuesioner. Kuesioner penelitian dari kuesioner identitas diri yang dimodifikasi dari Marcia (Erickson) oleh peneliti, oleh karena itu perlu dilakukan uji validitas dan reliabilitas yang didapatkan hasil uji $v=(0,342-0,999)$ dan uji $r=0,971$ dari 43 pertanyaan dan kuisioner Dukungan Sosial Sarason didapatkan hasil uji $v=(0,272-0,897)$ dan uji $r=$ 0,942 . Analisis univariat dan bivariat (chi square). 
HASIL DAN PEMBAHASAN

Analisis Univariat

Tabel 1. Distribusi Frekuensi Identitas Diri Responden Terhadap Remaja Penyintas

\begin{tabular}{ccc}
\hline Identitas diri & N & Persentase (\%) \\
\hline Identitas Diri Baik & 88 & 80,9 \\
\hline Identitas Diri tidak baik & 4 & 19,1 \\
\hline Total & 92 & 100
\end{tabular}

Dapat dilihat dari 92 responden menunjukkan bahwa frekuensi identitas diri baik memiliki jumlah terbanyak yaitu 88 responden
$(80,9 \%)$, dibandingkan jumlah identitas diri tidak baik hanya 4 responden $(19,1 \%)$.

Tabel 2. Distribusi Frekuensi Dukungan Sosial Responden Terhadap Remaja Penyintas

\begin{tabular}{ccc}
\hline Dukungan Social & N & Persentase (\%) \\
\hline $\begin{array}{c}\text { Dukungan Sosial } \\
\text { Rendah }\end{array}$ & 2 & 20 \\
\hline $\begin{array}{c}\text { Dukungan Sosial } \\
\text { Tinggi }\end{array}$ & 90 & 90 \\
\hline Total & 92 & 100 \\
\hline
\end{tabular}

Sedangkan dilihat dari 92 yaitu 90 responden (90\%), responden di frekuensi dukungan dibandingkan dengan dukungan social responden menunjukkan social rendah dengan jumlah 2 bahwa frekuensi dukungan social responden juga (20\%).

tinggi memiliki jumlah terbanyak

Analisis Bivariat

Tabel 3. Hubungan Identitas Diri dengan Remaja Penyintas Covid-19

\begin{tabular}{|c|c|c|c|c|c|c|}
\hline \multirow{3}{*}{$\begin{array}{l}\text { Identitas } \\
\text { diri }\end{array}$} & \multicolumn{2}{|c|}{ Remaja } & Penyintas & \multicolumn{2}{|l|}{ Total } & \multirow[t]{3}{*}{ OR } \\
\hline & \multicolumn{2}{|c|}{ Menerima } & $\begin{array}{c}\text { Tidak } \\
\text { Menerima }\end{array}$ & $\mathbf{N}$ & $\%$ & \\
\hline & $\mathbf{N}$ & $\%$ & $\mathbf{N} \quad \%$ & & & \\
\hline $\begin{array}{l}\text { Identitas } \\
\text { Diri Baik }\end{array}$ & 88 & 79,1 & 210,45 & 90 & 89,55 & \\
\hline $\begin{array}{l}\text { Identitas } \\
\text { Diri Tidak } \\
\text { Baik }\end{array}$ & 0 & 0 & 210,45 & 2 & 10,45 & $0,0000,50$ \\
\hline Total & 88 & 79,1 & 420,9 & 92 & 100 & \\
\hline
\end{tabular}


Dapat dilihat dari 92 responden menunjukkan bahwa terdapat 88 responden $(79,1 \%)$ dengan identitas diri baik yang menerima bahwa dirinya adalah penyintas Covid-19 atau pernah terpapar Covid-19 dan terdapat 2 respoden $(10,45 \%)$ dengan Identitas diri baik juga yang tidak menerima bahwa dirinya pernah terpapar Covid-19. Lalu terdapat 2 responden $(10,45 \%)$ dengan Identitas diri tidak baik yang tidak menerima dirinya adalah penyintas Covid-19.

Tabel 4. Hubungan Dukungan Sosial dengan Remaja Penyintas Covid-19

\begin{tabular}{|c|c|c|c|c|c|c|c|}
\hline \multirow{3}{*}{$\begin{array}{c}\text { Dukungan } \\
\text { Sosial }\end{array}$} & \multicolumn{2}{|c|}{ Remaja } & \multicolumn{2}{|c|}{ Penyintas } & \multicolumn{2}{|l|}{ Total } & \multirow[t]{3}{*}{ OR } \\
\hline & \multicolumn{2}{|c|}{ Menerima } & \multicolumn{2}{|c|}{$\begin{array}{c}\text { Tidak } \\
\text { Menerima }\end{array}$} & $N$ & $\%$ & \\
\hline & $\mathrm{N}$ & $\%$ & $N$ & $\%$ & & & \\
\hline $\begin{array}{l}\text { Dukungan } \\
\text { Sosial } \\
\text { Rendah }\end{array}$ & 0 & & 2 & 10,45 & 2 & 10,45 & \\
\hline $\begin{array}{l}\text { Dukungan } \\
\text { Sosial } \\
\text { Tinggi }\end{array}$ & 88 & 79,1 & 2 & 10,45 & 90 & 89,55 & $0,0000,50$ \\
\hline Total & 88 & 79,1 & 4 & 20,9 & 92 & 100 & \\
\hline
\end{tabular}

Dapat dilihat dari 92 responden menunjukkan bahwa terdapat 2 responden $(10,45 \%)$ dengan Dukungan sosial rendah tidak menerima bahwa dirinya adalah penyintas Covid-19 atau pernah terpapar Covid-19. Lalu terdapat 88 responden $(79,1 \%)$ dengan Dukungan sosial tinggi menerima bahwa dirinya adalah penyintas Covid-19 dan 2 responden $(10,45 \%)$ dengan Dukungan sosial tinggi tidak menerima bahwa dirinya adalah penyintas Covid-19.

Tabel 5. Hubungan Identitas Diri dan Dukungan Sosial Responden

\begin{tabular}{|c|c|c|c|c|c|}
\hline \multirow{3}{*}{ Identitas diri } & Dukungan & Sosial & \multicolumn{2}{|l|}{ Total } & \multirow[t]{3}{*}{$\mathbf{P}$} \\
\hline & Rendah & Tinggi & $\mathbf{N}$ & $\%$ & \\
\hline & $\%$ & $\mathbf{N} \quad \%$ & & & \\
\hline $\begin{array}{l}\text { Identitas Diri } \\
\text { Baik }\end{array}$ & 0 & 8879.1 & 88 & 79,1 & \\
\hline $\begin{array}{l}\text { Identitas Diri } \\
\text { Tidak Baik }\end{array}$ & 210,45 & 210,45 & 4 & 20,9 & $0,0000,50$ \\
\hline Total & 210,45 & 9089,55 & 92 & 100 & \\
\hline
\end{tabular}

Dan dapat dilihat juga dari 92 responden menunjukkan bahwa terdapat 2 responden $(10,45 \%)$ dengan identitas diri tidak baik mengalami dukungan social rendah.
Sedangkan terdapat 90 responden $(98,55 \%)$ dimana 2 respondennya dengan identitas diri tidak baik dan sisanya yaitu 88 responden dengan identitas diri baik mengalami 
dukungan sosial tinggi. Dari ketiga hubungan ini sama-sama mendapatkan hasil uji statistic ChiSquare dengan perolehan $\mathrm{p}$ value sebesar $\quad(0,000) \quad(p, 0,05) . \quad H 1$ diterima dan $\mathrm{HO}$ ditolak dapat diartikan terdapat hubungan antara identitas diri dengan dukungan sosial terhadap remaja penyintas Covid19. Diketahui juga terdapat nilai OR 0,50 yang bermakna peluang terjadinya hubungan antara identitas diri dengan dukungan sosial sebesar $(0,500)$ kali lipat.

\section{PEMBAHASAN \\ IDENTITAS DIRI DENGAN REMAJA PENYINTAS COVID-19}

Hasil penelitian didapatkan data bahwa terdapat 88 responden $(79,1 \%)$ dengan identitas diri baik yang menerima bahwa dirinya adalah penyintas Covid-19 atau pernah terpapar Covid-19 dan terdapat 2 respoden $(10,45 \%)$ dengan Identitas diri baik juga yang tidak menerima bahwa dirinya pernah terpapar Covid-19. Lalu terdapat 2 responden $(10,45 \%)$ dengan Identitas diri tidak baik yang tidak menerima dirinya adalah penyintas Covid-19. Sebelumnya sudah ada Teori Erikson yaitu identitas diri berkembang sepanjang kehidupan individu terutama pada masa remaja. Pembentukan identitas remaja bergantung pada faktor bawaan psikologis dan faktor lingkungan (Nicolso \& Ayers 2015). Identitas pada remaja akhir adalah tahap pertumbuhan ego remaja yang berkaitan dengan penilaian aspek kepribadian, keterhambatan dan ketercapaian. Menurut konsep tahap yang paling penting dalam perkembangan remaja akhir adalah tahap kelima (identity versus role confusion). (Marcia 1993, dalam Erikson 2016).

\section{DUKUNGAN SOSIAL DENGAN REMAJA PENINTAS COVID-19}

Hasil penelitian didapatkan data bahwa terdapat 2 responden $(10,45 \%)$ dengan Dukungan sosial rendah tidak menerima bahwa dirinya adalah penyintas Covid-19 atau pernah terpapar Covid-19. Lalu terdapat 88 responden $(\mathbf{7 9}, 1 \%)$ dengan Dukungan sosial tinggi menerima bahwa dirinya adalah penyintas Covid-19 dan 2 responden $(10,45 \%)$ dengan Dukungan sosial tinggi tidak menerima bahwa dirinya adalah penyintas Covid-19. Karna penelitian ini terdapatnya hubungan maka selaras dengan Teori Dukungan Social Sarason yang isi teorinya menekankan pada dukungan social seseorang, dimana dukungan social sangatlah berarti dan penting bagi setiap individu baik dari usia, jenis kelamin dan latar belakang apapun. Dengan adanya dukungan sosial itu selalu berkaitan dengan dua hal yaitu pola persepsi individu terhadap seseorang yang dapat diandalkan dalam membantu menyelesaikan masalah, serta tingkatan kepuasan dukungan yang diterima terkait dengan pola persepsi individu yang kebutuhan harus terpenuhi. Dukungan sosial mempunyai pengaruh yang kuat dalam keberlangsungan hidup seseorang. Dukungan sosial dapat diperoleh dari berbagai sumber seperti, teman, keluarga, sahabat, guru, psikolog, tetangga tau yang lain. Pengembangan dan pengimplementasian dukungan sosial sangat diperlukan oleh manusia dalam menjalankan hidup bersosial. Dengan adanya dukungan sosial yang telah diberikan, menunjukkan hubungan interpersonal yang melindungi individu terhadap konsekuensi stres. Dukungan sosial yang diterima dapat membuat individu dapat membuat individu merasa tenang, diperhatikan, dicintai, timbul rasa 
percaya diri dan kompeten. Hubungan sosial yang supportif secara sosial juga meredam efek stres, membantu orang mengatasi stres dan menambah kesehatan. Selain itu, dukungan sosial bisa efektif dalam mengatasi takanan psikologis pada masa-masa sulit dan menekan. Maka, penilaian positif terhadap dukungan sosial mengartikan bahwa individu mempersepsi dukungan yang diberikan oleh individu lain telah diterima dengan baik dan sesuai dengan kebutuhan yang diperlukan. Sebaliknya, penilaian negatif terhadap dukungan sosial yang diberikan tidak dapat diterima dan dirasakan dengan baik karena kurang dengan kubutuhan yang dimilikinya. Sarafino, Sarason (dalam Winda, 2016).

\section{HUBUNGAN IDENTITAS DIRI DENGAN DUKUNGAN SOSIAL DENGAN REMAJA PENYINTAS COVID-19}

Dari data yang didapatkan menunjukkan bahwa terdapat 2 responden $(10,45 \%)$ dengan identitas diri tidak baik mengalami dukungan social rendah. Sedangkan terdapat 90 responden $(98,55 \%)$ dimana 2 respondennya dengan identitas diri tidak baik dan sisanya yaitu 88 responden dengan identitas diri baik mengalami dukungan sosial tinggi.Karna dari penelitian ini terdapatnya hubungan yang positif antara Identitas Diri dengan Dukungan Sosial maka penelitian ini sejalan dengan teori penelitian yang dikemukakan oleh Lancet Psychiatry 2020, Michael Bloomfield 2020 dan Harrison 2020 yang dikatakan hampir serupa bahwa penyintas Covid19 kurang lebih beresiko lebih tinggi mengalami masalah kesehatan mental, terlebih alih-alih terdapat stigma negative dan kurangnya dukungan sosial yang menyebabkan rendah diri dan kehilangan identitas diri khususnya remaja penyintas Covid-19.Pada penelitian ini, hasil yang didapatkan pada wawancara awal atau uji awal dan uji akhir. Dalam hasilnya yang didapatkan tidak terlalu jauh, terdapat beberapa remaja sejumlah 4 orang yang memiliki pandangan yang negatif terhadap dirinya setelah menjadi penyintas Covid19 karena merasa dari segi fisik atau penampilan yang buruk, lemah, dan mudah sakit. Lalu dari segi psikologis yang buruk, hubungan spiritual dan sosial yang rendah juga yang diakibatkan dari berbagai lain hal seperti kurangnya kepercayaan diri, sering di bully, tidak adanya kawan atau sandaran diri meskipun ada keluarga di dekatnya tetapi tidak merasa aman dan nyaman, bahkan kurangnya keyakinan akan spiritual itu individu sendiri yang sudah teracuni akan ketakutan, kepercayaan dan doktrin orang lain atau diri sendiri. Lebih dari itu kita sebagai manusia sudah sewajarnya merasakan takut, sakit, sedih, bahagia, semangat, ceria dan berbagai macam rasa dan pemikiran, tapi kita harus ingat bahwa sejatinya kesempurnaan milik sang pencipta dan kita harus terus berjalan, berusaha dan berdoa. Melakukan yang terbaik sesuai versi masingmasing, saling mensupport, mengedukasi dan menghargai akan perbedaan. Di situ akan tercipta kebahagiaan di atas perbedaan.

\section{KESIMPULAN}

Hasil output uji statistic Chisquare dengan diperoleh $P$ Value sebesar $(0,000)>$ nilai a $(0,05)$. H1 diterima dan $\mathrm{HO}$ ditolak, dengan demikian dapat diartikan ada hubungan dari kejadian Covid-19 berdasarkan identitas diri dan dukungan sosial terhadap remaja penyintas Covid-19. Penelitian ini diharapkan dapat dijadikan sebagai 
informasi tambahan dan sarana untuk peneliti selanjutnya tentang analisa kejadian Covid-19 berdasarkan identitas diri dan

\section{DAFTAR PUSTAKA}

Allegra, A., Gioacchino, M. Di, Tonacci, A., Musolino, C., \& Gangemi, S. (2020). Immunopathology of SARSCoV2 Infection : Immune Cells and Mediators, Prognostic Factors, and Immune Therapeutic Implications . Journal of Molecular Sciences, 1-19.

Almuttaqi, A. Ibrahim. (2020). Kekacauan Respons Terhadap COVID-19 Di Indonesia. Thc Insigjts, 1-7.

BMJ Best Practice, W. M. (2020). COVID 197 Cardiovaskular disease, complications.

CDC. (2020). Interim Additional Guidance for Infection Prevention and Control Recommendations for Patients with Suspected or Confirmed COVID-19 in Outpatient Hemodialysis Facilities. Chinese Journal of Nephrology, 4-82.

Detik Health. (2021). Inikah Penyebab Kematian Tertinggi Pasien COVID-19 di Indonesia?

Emzir. (2010). Metodologi Penelitian Pendidikan Kuantitatif \& Kualitatif.

Guan, W. N. (2020). Clinical Characteristics of Coronavirus Disease 2019 in China. The New England Journal of Medicine, 17081720.

Handayani,D., Hadi, D. R., Isbaniah, F., Burhan, E., \& Agustin, H. (2020). Penyakit Virus Corona 2019. Jurnal Respirologi Indonesia, 119-129. dukungan sosial terhadap remaja penyintas Covid-19.

Healthline. (2021). What to Know About COVID-19 and Pneumonia.

Huang, C. W. (2020). Clinical Features of Patients Infected with 2019 Novel Coronavirus in Wuhan, China. Lancet Psychology, 497-506.

Kemenkes RI. (2020, August 31). Situasi Terkini Perkembangan Novel Coronavirus.

Kumar, V. S., Mukherjee, S., Harne, P. S., Subedi, A., Ganapathy, M. K., Patthipati, V. S., \& Sapkota, B. (2020). Novelty in the Gut : A Systematic Review Analysis of the Gastrointestinal

Manifestations of Covid-19. BMJ Open Gastroenterology, 1-9.

Marcia, J. E. (n.d.). Development and validation of ego identity status. Ego Identity status : reltionship to change in self esteem. Journal of Personality and social psychology, 118-133 dan 551558.

Meng, H., Xiong, R., He, R., Lin, W., Hao, B., Zhang, L., \& Lu, Z. . (2020). CT Imaging and Clinical Course of Asymptomatic Cases with Covid-19 Pneumonia at Admission in Wuhan. China. Journal of Infection, e33e39.

Meng, H., Xiong, R., He, R., Lin, W., Hao, B., Zhang, L., \& Lu, Z. (2020). han,China. China Journal of Infection, e33339.

Nham, E., Ko, J.-H., Jeong, B.-H., Huh, K., Cho, S. Y., Kang, C.I., Peck, K. R. (2020). Severe Thrombocytopenia in a 
Patient with COVID-19. Infection and Chemotherapy Case Report, 1-5.

Nurjanah. (2020). Semangat Bela Negara Untuk Menghadapi COVID-19 Di Indonesia.

Organization, World Health. (2021). COVID-19: Vulnerable and High Risk Group. The Pediatric Infectious Disease Journal. Diakses pada 2021. Acute Kidney Injury and COVID-19.

Penyakit, D. J. (2020). Pedoman Kesiapsagaan Menghadapi Coronavirus Disease .

Singh, Jaspreet. (2020). COVID-19's Impact on the Society. Electronic Research.

Susilo, A., Rumende, C. M., Pitoyo, C. W., Santoso, W. D., Yulianti, M., Sinto, R. Yunihastuti, E.,. (2020). Coronavirus Disease 2019. Jurnal Penyakit Dalam Indonesia. Tinjauan Literartur Terkini, 45-67.

Vollono, C., Rollo, E., Romozzi, M., Frisullo, G., Servidei, S., Borghetti, A., \& Calabresi, P. (2020). Focal Status Epilepticus as Unique Clinical Feature of Covid-19. A Case Report Europian Journal of Epilepsy, 109-112.

World Health Organization . (2020, August 31). World Health Organization Coronavirus Disease 2019 Global Situation 2020.

Xiao, F. T. (2020). Evidence for Gastrointestinal Infection of SARS-CoV-2. Elsevier Gastroenterology, 18311833.

Xu, X. C. (2020). Evolution of Novel Coronavirus from The Ongoing Wuhan Outbreak and Modeling of Its Spike Protein For Risk of Human Transmission. Science China Life , 4567-460.
Ye, Q., Wang, B., \& Mao, J. (2020). The Pathogenesis and Treatment of the Cytokine Storm in COVID-19. Journal of Infection, 607-613.

Zhang, H., Penninger, J. M., Li, Y., Zhoung, N., \& Slutsky, A. S. (2020). Angiotensin Converting Enzyme 2 (ACE2) as SARS CoV-2 Receptor : Molecular Mechanisms and Potential Therapeutic Target. Intencive Care Medicine, 586-590.

Zhu, N., Zhang, D., Wang, W., Li, X., Yang, B., Song, J., Tan, W. (2020). A Novel Coronavirus from Patient with Pneumonia in China 2019. The New England Journal of Medicine, 727-733. 